\title{
POTENSI USAHA MASYARAKAT DESA KEDONDONG DI HTI HUTAN KETAPANG INDUSTRI KABUPATEN KETAPANG
}

\author{
(Potential Business for Local Community in Kedondong Village In HTI Hutan Ketapang \\ Industri Ketapang District)
}

\section{Pandi, H. Sofiyan Zainal, Dirhamsyah}

Fakultas Kehutanan Universitas Tanjungpura Pontianak. Jl. Daya Nasional Pontianak 78124

Email: muhamadpandishut@gmail.com

\begin{abstract}
The purpose of this study was to obtain information business potentials for local community in Kedondong village that could develop with the establishment of PT Hutan Ketapang Industri. Analyze the potential of local resources and the economic impact of the bussines potensial at Kedondong village take by direct interviews to respodent. This research was conducted in Kedondong Village, Kendawangan District, Ketapang Regency with an effective period of 4 weeks in the field. Equipment used in this study included a list of questions, stationery, cameras and voice recorders. Data collection is done using survey methods and direct observation in the field. Sampling was done by Slovin technique. Based on the results of the study, local community efforts to business potential in Kedondong Village with establisment PT HKI, which is done by the community including utilizing vacant land to be used as agricultural land, gardens, livestock or, among others, opening business opportunities such as food stalls, workshops, agriculture and fishery.
\end{abstract}

Keywords: Business Potential, Kedondong village, PT HKI

\section{PENDAHULUAN}

Secara global, peran hutan tanam industri semakin penting, khususnya untuk menuhi kebutuhan kayu seirinya menurunya produksi kayu dari hutan alam sejak akhir 1980 (Warwan, 2014). Hutan tanaman menyumbang sekitar sepertiga produksi kayu bulat industri dunia pada 2012 (Jurgensen, 2014). Mereka juga menyediakan produk hutan bukan kayu dan sejumlah barang dan jasa lingkungan (Brockerhoff, 2013), dan umumnya menyokong penghidupan lokal serta pembangunan desa, khususnya ditanam oleh petani kecil (Rohadi, 2010). Menurut estematis terkini, area global hutan tanam (termasuk hutan semi - alami) meningkat dari 167 juta hektar menjadi 280 juta hektar dari 1990 sampai 2015 (Piyan, 2015), dengan lebih dari 100 juta hektar hutan tanaman lain didedikasikn untuk fungsi perlindungan seperti konservasi tanah dan air atau sekuestrasi karbon. Produk kayu global, termasuk bubur kayu dan kertas. Hutan Tanam Industri diasumsikan memiliki produktivitas dan efisiensi lebih tinggi dibanding hutan tanaman yang ditanam oleh petani kecil.

Penyelenggaraan hutan desa dimaksudkan untuk memberikan akses kepada masyarakat setempat melalui lembaga desa dalam memanfaatkan sumberdaya hutan secara lestari serta bertujuan meningkatkan kesejahteraan masyarakat setempat secara berkelanjutan Pengembangan Hutan Desa menurut Alam $d k k$. (2003), intinya lebih diarahkan untuk meningkatkan fungsi-fungsi hutan secara 
optimal, meningkatkan kesejahteraan masyarakat, melalui suatu sistem pengelolaan yang menempatkan masyarakat desa sebagai pelaku utama, mitra kerja, dan sebagai pihak yang harus mendapat bagian kesejahteraan yang memadai dari kegiatan pengelolaan hutan. Hutan desa lebih bertumpu pada kemandirian masyarakat desa melalui suatu lembaga desa atau BUMD (Badan Usaha Milik Desa). Pengambilan keputusan diadakan secara musyawarah antara masyarakat desa dengan BUMD.

Keberadaan Hutan Tanaman Industri yang dikelola oleh PT. Hutan Ketapang Industri, diharapkan dapat memberikan dampak positif bagi masyarakat sekitar, antara lain; 1) Dapat membuka kesempatan berusaha masyarakat 2) Diharapkan dapat berperan dalam meningkatkan kesejahteraan masyarakat dari segi pendapatan rumah tangga. Perusahaan dituntut memberikan kontribusi dalam kehidupan komunitas lokal sebagai rekan dalam kehidupan masyarakat artinya bahwa perusaan harus mempunyai kewajiban sosial terhadap komunitas lainya sebagai sesuatu yang sejajar dan saling membutuhkan (Rudito, 2004).

Permasalahan yang menjadi fokus pemecahannya yaitu terkait dengan kemiskinan yang terjadi pada masyarakat .oleh karena itu untuk mengatasi permasalahan tersebut ada upaya yang selama ini telah banyak dirancang oleh berbagai pihak untuk mengatasi kemiskinan. Upaya-upaya pemberatasan kemiskinan mulai digalakkan oleh berbagai sektor mulai dari sektor pemerintahan dengan program-program unggulannya hingga Lembaga Swadaya Masyarakat melalui usaha yang dilakukan yang tujuannya adalah mengurangi angka kemiskinan dan mensejahterakan masyarakat.Salah satu upaya yang dilakukan oleh berbagai pihak tersebut adalah dengan jalan pemberdayaan masyarakat (Widayanti, 2012 Wahyuni (2013) menyatakan bahwa apabila potensi usaha dikembangkan secara baik maka dapat mendorong tumbuhnya perekonomian secara menyeluruh.

Struktur ekonomi wilayah dipengaruhi oleh potensi daerah yang dimiliki wilayah itu sendiri yaitu sumber daya alam seperti tanah, iklim, hasil tambang, hasil laut, dan sumber daya manusia seperti tenga kerja yang berpendidikan dan memiliki keterampilan untuk dapat mengolah sumber daya alam yang ada. teoritis pembangunan industri sebenarnya memiliki manfaat positif antara lain menyerap tenaga kerja meningkatkan produktivitas ekonomi.dan miningkatkan jenis-jenis potensi usaha di lingkungan desa serta menjadi aset pembangunan nasional daerah Oleh karena itu, tanggung jawab sosial yang diberikan oleh perusahaan terhadap komunitas yang ada di sekitarnya lebih bersifat partisipasi. oleh karena itudengan adanya PT Hutan Ketapang Industri dapat membuka peluang bagi masyarakat Desa Kedondong untuk meningkatkan nilai ekonomi yang ada di sekitar kawasan PT Hutan Ketapang Indust. Tujuan penelitian ini adalah untuk mengetahui potensi usaha dan peluang kerja yang dapat dikembangkan oleh masyarakat Desa Kedondong dengan berdirinya PT Hutan Ketapang Industi. 


\section{METODE PENELITIAN}

Penelitian dilaksanakan di Desa Kedondong, Kecamatan Kendawangan, Kabupaten Ketapang, Lokasi penelitian ini terbagi tiga Dusun yaitu: Dusun Sungai Nanas, Dusun Kelampai dan Air Jelemuk penelitian dilakukan selama satu bulan dimulai 2 Febuari-Maret 2019. Alat yang di gunakan dalam penelitian yaitu Jenis Peralatan Kuesioner Penelitian, Kamera, Peralatan ATK, Perekam,

\section{Objek Penelitian}

Objek yang diteliti dalam penelitian yaitu, Pontensi Usaha Masyarakat Desa Kedondong di PT Ketapang Industri Kecamatan Kendawangan Kabupaten Ketapang.

\section{Populasi dan Teknik Pengambilan Sampel}

Menurut (Sugiyono, 2011). populasi adalah wilayah generalisasi yang terdiri atas objek/subjek yang mempunyai kualitas dan karakteristik tertentu yang ditetapkan oleh peneliti untuk dipelajari dan kemudian ditarik kesimpulannya. populasi $380 \mathrm{KK}$ dalam penelitian ini adalah kepala keluarga (KK) yang bertempat tinggal di Desa Kedondong yang terdiri dari 3 (tiga) dusun Sungai Nanas dusun Kelampai dan Air Jelemuk. penelitian dari tiga (tiga) dusun dan yang diambil sebanyak $80 \mathrm{KK}$.

Sampel adalah bagian dari jumlah dan karakteristik yang dimiliki oleh populasi. populasi besar, dan peneliti tidak mungkin mempelajari semua yang ada pada populasi, misalnya karena keterbatasan biaya, tenaga dan waktu, maka dapat menggunakan sampel yang diambil dari populasi tersebut (Sugiyono, 2011).
Penetuan sempel dilakukan dengan rumus Slovin sebagai berikut:

$n=\frac{N}{1+N(e)^{2}}$

Dimana :

$\mathrm{n}=$ Sampel respoden

$\mathrm{N}=$ Populasi respoden

$\mathrm{e}=$ Tingkat ketelitian

dapat ditolerir atau diinginkan, dalam penelitian ini digunakan $10 \%$

$=\frac{380}{1+380 /(10)^{2}}$

$=\frac{380}{1+3,8}$

$=\frac{380}{4,8}$

$=80$

Kirikteria masyarakat sebagai Kepala Keluarga yang dijadikan responden penelitian adalah sebagai berikut:

1. Berdomisili atau menetap minimal 5 tahun.

2. Umur minimal 18 tahun sampai 70

3. Sehat jasmani dan rohani.

\section{HASIL DAN PEMBAHASAN}

Karakteristik Respoden Jenis Pekerjaan

Pekerjaan pokok masyarakat yang bermukim di sekitar hutan maupun di sekitar perusahan PT HKI di Desa Kedondong umunya memiliki beragam macam jenis. Pada tabel di atas untuk jenis pekerjaan dibagi menjadi 4 yaitu wirausaha seperti wirausaha, seperti bedagang. lainya sebagai buruh kariyawan/guru, dan swasta. Setiap manusia memiliki kebutuhan untuk menjalani kehidupan mereka. Kebutuhan pokok dibagi menjadi tiga yaitu pangan, sandang, dan papan. Untuk memenuhi kebutuhan tersebut setiap manusia mencari pekerjaan untuk mendapatkan penghasilan. Jenis pekerjaan seorang responden sangat berpengaruh terhadap pendapatannya. 
Tabel 1. Jenis Pekerjaaan Responden Di di Dusun Kelampai (Responden Job Type at Kelampai Subvillage)

\begin{tabular}{llcc}
\hline No & Jenis Pekerjaan & $\begin{array}{c}\text { Jumlah Respoden } \\
\text { ( Orang) }\end{array}$ & Persentase (\%) \\
\hline 1 & Wirausaha & 2 & 5,0 \\
2 & Buruh Karyawan & 21 & 63,6 \\
3 & Guru & 4 & 12,1 \\
4 & Swasta & 6 & 18,1 \\
\hline & Jumlah & 33 & 100 \\
\hline
\end{tabular}

\section{Sumber : Analisis data}

Jenis pekerjaan di Desa Kedondong dari dusun beragam macam pekerjaan seperti buruh kariyawan, dari 26 responden dengan persentase $(26,9 \%)$ ada juga jenis pekerjaan yang digeluti masyarakat Kedondong di antaranya petani wirausaha seperti petani cabai, berkebun karet, berkebun buah dan sayuran sahang, mebel, tukang, disini dapat kita simpulkan dari tabel diatas kebanyakan sebagian masyarakat masih bergantungan dengan bekerja di perusahaan. Jenis pekerjaan juga merupakan salah satu faktor yang mempengaruhi pendapatan (Cahyono,1998).

Tabel 2. Jenis Pekerjaaan Responden di Dusun Sungai Nanas (Responden Job Type at Nanas Subvillage)

\begin{tabular}{llcl}
\hline No & Jenis Pekerjaan & $\begin{array}{c}\text { Jumlah Respoden } \\
\text { ( Orang) }\end{array}$ & Persentase (\%) \\
\hline 1 & Wirausaha & 7 & 26,9 \\
2 & Buruh Kariyawan & 10 & 38,4 \\
3 & Guru & 3 & 11,5 \\
4 & Swasta & 6 & 23,0 \\
\hline & Jumlah & 26 & 100 \\
\hline
\end{tabular}

Sumber : Analisis data 2019

Jenis pekerjaan di Desa Kedondong dari dusun Air jelemuk beragam macam pekerjaan, dari tabel diatas kebanyakan masyarakat bekerja sebagai buruh kariyawan yaitu sekitar 9 responden dengan persentase $(42,8 \%)$ ada juga jenis pekerjaan yang digeluti masyarakat desa Kedondong di dusun air jelemuk di antaranya berternak wirausaha, disini dapat kita simpulkan dari tabel diatas kebanyakan sebagian masyarakat masih bergantungan dengan bekerja di perusahaan namun disisi lain masyarakat
Desa Kedondong menyadari semakin ada nya aktifitas perusahaan di desa mereka semakin giat lagi dalam bekerja dari segi apa pun. Menurut Soeharjo Sasaran akhir dari seseorang dalam mengelola kegiatannya adalah pendapatan yang maksimal sehingga segala sesuatu bisa tercapai dengan baik dan kebutuhan rumah tangga dapat terpenuhi (Soeharjo, 1973). dalam kehidupannya, manusia harus memenuhi kebutuhan materialnya untuk melangsungkan hidupnya, hal tersebut 
dapat diwujudkan melalui pranatapranata mereka dengan memanfaatkan sumber daya alam, modal dan tenaga kerja yang terbatas. Studi mengenai hal tersebut disebut ilmu ekonomi. Salah satu faktor yang berpengaruh dalam ekonomi masyarakat adalah tingkat kemauan dan kerja keras masyarakat dalam menghasilkan pendapatan yang di ingginkan sehingga segala sesuatu bisa dipenuhi dalam kebutuhan sehari hari.

Tabel 3. Jenis Pekerjaaan Responden Dusun Air jelemuk (Responden Job Type at Jelemuk Subvillage)

\begin{tabular}{llcl}
\hline No & Jenis Pekerjaan & $\begin{array}{c}\text { Jumlah Respoden } \\
\text { ( Orang) }\end{array}$ & Persentase (\%) \\
\hline 1 & Wirausaha & 5 & 23,8 \\
2 & Buruh Kariyawan & 9 & 42,8 \\
3 & Guru & 2 & 9,5 \\
4 & Swasta & 5 & 23,8 \\
\hline & Jumlah & 21 & 100 \\
\hline
\end{tabular}

Sumber : Analisis data 2019

Jenis Potensi Usaha yang dapat dikembangkan oleh masyarakat Desa Kedondong setalah adanya PT HKI

Berdasarkan hasil surve di lapangan dari 3 dusun yaitu dusun Air jelemuk dusun Sungai nanas dan dusun Kelampai melalui wawancara lansung dari 80 repoden potensi yang dikembangkan oleh masyarakat di Desa Kedondong setelah adanya PT HKI disajikan pada tabel sebagai berikut.

\section{Tabel 4. Jenis Pekerjaaan Responden Di Desa Kedondong (Responden Job Type at} Kedondong Village)

\begin{tabular}{llcc}
\hline No Jenis pekerjaan & $\begin{array}{c}\text { Jumlah Responden } \\
\text { (Orang) }\end{array}$ & Persentase (\%) \\
\hline 1 & Warung sembako warung makan . & 1 & 14,2 \\
2 & Bengkel - warung makan . & 1 & 14,2 \\
3 & Ternak Ayam -Petani. & 1 & 14,2 \\
4 & Petani Sahang Ternak Ikan. & 1 & 14,2 \\
5 & Warung makan - Warung & 1 & 14,2 \\
& Sembako. & 1 & 14,2 \\
6 & Ketua RT - Pegusaha Rotan. & 1 & 14,2 \\
7 & Petani sayuran - Satpam HKI. & & 100 \\
\hline
\end{tabular}

Sumber: Analisis data 2019

Berdasarkan hasil menujukan rata Persentase keseluruhan (14,2) .dan Jenis pekerjaan masyarakat di Desa Kedondong dari tiga dusun beragam macam pekerjaan namun dari hasil surve

dilapangan hanya berapa bagian yang berpengaruh dan dikembangkan oleh masyarakat desa kedondong dari segi usaha warung sembako, ternak, warung makan,bengkel, dan pertanian. 
Tabel 5. Jenis Pekerjaan masyarakat yang bekerja di PT HKI ((Responden Job Type at PT HKI)

\begin{tabular}{llcc}
\hline No & Jenis Pekerjaan & Jumlah Responden & Persentase (\%) \\
\hline 1 & Mandor & 2 & 5.0 \\
2 & Humas Saklak & 2 & 5.0 \\
3 & Admin kantor & 4 & 10.0 \\
4 & Satpam & 4 & 10.0 \\
5 & Kariyawan Racun Semprot & 10 & 25.0 \\
6 & Kariyawan pembibitan & 8 & 20.0 \\
7 & Kariyawan Pupuk & 10 & 25.0 \\
\hline & Jumlah & 40 & 100 \\
\hline
\end{tabular}

Sumber : Analisis data 2019

Berdasarkan hasil penelitian yang di uraikan pada tabel 5 bahwa persepsi tenaga kerja terhadap keberadaan PT HKI di Desa Kedondong sangat megurangi angka penganguran dan meningkatkan pedapatan rumah tangga masyarakat Desa Kedondong. Hal ini dapat dilihat di tabel banyaknya pekerjaan yang digeluti masyarakat Desa Kedondong yang tadinya hanya megandalkan nureh/garet, berburu dan petani tentu tidak terlalu mencukupi untuk kebutuhan sehari hari hari. namun Setelah bekerja di PT HKI masyarakat dapat merasakan lebih dari cukup. Masyarakat yang sudah bekerja lama selain mendapatkan gajih pokok mendapat kebijakan dari perusahaan seperti KHT atau disebut dengan Kariyawan Harian Tetap. Masyarakat yang bekerja di PT HKI mendapat beras perbulan dan ditambah lagi mendapatkan kartu BPJS, THR, Jamsotek dan Tujangan Hari Tua. Karyawan untuk mendapatkan kebijakan perusahaan tersebut minimal harus bekerja paling lambat 3 bulan atau 5 bulan setelah itu baru ditetapkan. Pekerja Kariyawan Harian Lepas (KHL) tidak menapatkan bantuan seperti beras maupun yang lainya rata gajih pokok kariyawan PT HKI RP.2.340.000 rupiah dari mulai jam 7 pagi sampai jam 12 siang namun jika ada lembur minimal pendapatan perbulan Rp.3.120.000 perbulan akan tetapi teragantung jabatan maupun pekerjaan yang dikerjakan sedang seperti Satpam Rp. 3.800.00 sedangkan mandor hampir RP. 4.000 .000 perbulan.

Bedasarkan hasil penelitian dan keterangan masyarakat Desa Kedondong, dari 80 responden di tiga Dusun yaitu Dusun Kelampai Dusun Sungai Nanas dan Dusun Air Jelemuk terbagi menjadi 47 respoden yang merasakan dampak dan berpengaruh dalam Potensi Usaha maupun Lapangan Pekerjaan, yaitu 40 responden bekerja di PT HKI dan 7 responden merasakan usaha mereka bertambah dan berkembang. Sebanyak 33 respoden sebelum adanya PT HKI dan sesudah adanya PT HKI di Desa Kodondong mereka merasakan bahwa jenis pekerjaan maupun usaha tidak mengalami perubahaan jenis pekerjaan maupun jenis usaha dari dulu hingga sekarang tetap itu menjadi pendapatan meraka, suatu usaha investasi dalam kegiatan pembangunan memiliki kemampuan potensial menimbulkan dampak (dampak merupakan pengaruh yang mendatangkan 
akibat baik positif maupun negatif). Konsep dampak diartikan sebagai pengaruh munculnya aktifitas manusia dalam pembangunan terhadap lingkungan termasuk manusia.

Soemartono (2011) menjelaskan bahwa pada dasarnya sasaran pembangunan adalah menaikkan tingkat kesejahteraan rakyat, akan tetapi aktifitas pembangunan menimbulkan efek samping yang tidak direncanakan di luar sasaran yang disebut dampak. Dampak dapat bersifat biofisik, sosial, ekonomi, dan budaya yang berpengaruh terhadap sasaran yang ingin dicapai.

Menurut Soedharto (2000). dampak sosial adalah konsekuensi sosial yang menimbulkan akibat dari suatu kegiatan pembangunan ataupun penerapan suatu kebijakan dan program merupakan perubahan yang terjadi pada manusia dan masyarakat yang diakibatkan oleh aktifitas pembangunan perusahaan diwilayah permukiman. Menurut Tambunan dan Djaimi (2010) program industrialisasi pedesaan merupakan usaha untuk memajukan masyarakat yang masih agraris kearah masyarakat industrial. Industrialisasi pedesaan bertujuan antara lain mendorong pertumbuhan pedesaan dengan mendiversifikasi sumber pendapatan, meningkatkan kesempatan kerja baru, meningkatkan produktivitas tenaga kerja dan usaha, mendekatkan hubungan fungsional sektor pertanian dan sektor usaha, mengendalikan urbanisasi dan mengurangi kemiskinan di pedesaan.

Pendapatan suatu kegiatan ekonomi adalah selisih antara penerimaan yang di peroleh dari suatu kegiatan dengan biaya yang di keluarkan untuk melaksanakan kegiatan tersebut. Berhasilnya suatu kegiatan dapat di lihat dari tingkat pendapatan yang di terima dari kegiatan. berdasarkan (Bappenas, 2000). status kesejahteraan dapat diukur berdasarkan proporsi pengeluaran rumah tangga. Rumah tangga dapat dikatakan sejahtera apabila proporsi pengeluaran untuk kebutuhan pokok sebanding atau lebih rendah dari proporsi pengeluaran untuk kebutuhan bukan pokok. Sebaliknya, rumah tangga dengan proporsi pengeluran kebutuhan pokok lebih besar dibandingkan dengan pengeluaran untuk kebutuhan bukan pokok, dapat dikategorikan sebagai rumah tangga dengan status kesejahteraan rendah.

\section{KESIMPULAN}

Berdasarkan uraian hasil penelitian dan untuk menjawab permasalahan dari penelitian ini, maka dapat dikemukakan kesimpulan sebagai berikut :

1. Hasil penelitian di lapangan dari 80 responden di Desa Kedondong yaitu teridiri 47 respoden mengalami dampak perubahaan positif setelah adanyanya PT HKI yaitu masyarakat Desa Kedondong mengalami perubahaan dari segi usaha yaitu mengembangkn potensi di sekitar Desa Kedondong seperti membuka warung makan, sembako, bengkel, pertanian, peternakan, dan perikanan dan menfaatkan hasil hutan dijadikan kerajingan tagan seperti pemanfaatan rotan.

2. Masyarakat merespon baik dengan keberadaan Hutan Tanam Industri berada di Desa Kedondong tentunya dapat dirasakan dari masyarakat yaitu 
adanya perubahaan sesudah adanya perusahan dibandingkan sebelum nya. Adanya kemajuan dan kemauan masyarakat dalam melakukan perubahaan sejak adanya perusahaan. Ini dapat dilihat dari karakter masyarakat yang antusias dalam mengembangkan usaha dan menfaatkan sumber daya alam disekitar hutan.

\section{UCAPAN TERIMA KASIH}

Saya selaku penulis mengucapkan banyak terima kasih kepada PT HKI dan masyarakat Desa Kedondong yang sudah mendukung terlaksananya penelitian ini.

\section{DAFTAR FUSTAKA}

Bappenas. 2000. Struktur Pendapatan Rumah Tangga Petani Sawah di Pedesaan Jawa Barat Prosiding Perubahan Ekonomi Pedesaan menuju Ekonomi Berimbang. Bogor: Pusat Penelitian Agro Ekonomi.

Brockerhoff, Jactel H, Parrotta JA dan Ferraz SFB. et al. 2013. Role of eucalypt and otherplanted forests in biodiversity conservationand the provision of biodiversityrelatedecosystem services. Forest Ecology and Management.

Cahyono, \& S. Andy. 1998. Karakteristik Sosial Ekonomi yang Mempengaruhi Pendapatan Rumah Tangga Penyadap Getah Pinus di Desa Somagede, Kebumen, Jawa Tengah. Jurnal UGM.

Djaimi MB. 2010. Rekonstruksi Strategi Industrialisasi. Yogyakarta (ID): Graha Ilmu.

Jurgensen C, Kollert W \& Lebedys A. 2014.Assessment of Industrial Roundwood Production from Planted Forests. Rome: FAO.
Piyan T, Carnus J-M, Freer-Smith P, Kimberley M, Kollert W, Liu S, Orazio C, Rodriguez L, Silva LN dan Wingfield MJ. 2015. Changes inplanted forests and future global implications. Forest Ecology and Management.

Poerwandari, \& E. Kristi. 1999. Metode Penelitian Sosial. Jakarta: Universitas Terbuka.

Rohadi D, Kallio M, Krisnawati $\mathrm{H}$ dan Manalu P. 2010. Economic incentives and householdperceptions on smallholder timber plantations: Lessons from case studies in Indonesia.Presentation. Montpellier Conference, 24-26March 2010, Montpellier. Bogor, Indonesia: CIFOR.

Soearjo. 1973. Pidato Mentri Kehutanan. Pros. Sem. Nas. Ancaman. Terhadap Hutan Tanaman Industri. Fakultas Metamtika dan Ilmu Pengetahuan Alam UI dan Depertemen Kehutanan.

Widayanti, S. 2012. Pemberdayaan Masyarakat: Pendekatan Teoritis. Jurnal Welfare

Wahyuni, R. 2013. Analisis Identifikasi Sektor Unggulan Di Propinsi Jawa TimurTahun2010 (Pendekatan Input Output). Tesis tidak dipublikasikan: Program Pascasarjana Universitas Brawijaya Malang.

Warman RD. 2014. Global wood production fromnatural forests has peaked. Biodiversity and Conservation. 